\title{
PENGARUH JUMLAH BARIS KEDELAI DAN DOSIS PUPUK ORGANIK TERHADAP PERTUMBUHAN DAN HASIL UBI JALAR PADA SISTEM TUMPANGSARI UBI JALAR-KEDELAI
}

\author{
The Effect Of The Number Of Soybean Lines And The Dosage Of Organic \\ Fertilizer On TheGrowth And Yield Of Yam (Sweet Potato) In The Intercropping \\ System Of Yam (Sweet Potato)-Soybean \\ Wahyu Sulistyorini, Setiyono, \\ Program Studi Agroteknologi, Fakultas Pertanian, Universitas Jember \\ Email : wahyusulistyorini0906@gmail.com
}

\begin{abstract}
ABSTRAK
Salah satu alternatif yang dapat diterapkan untuk meningkatkan potensi produksi tanaman dalam rangka memenuhi kebutuhan pangan akibat semakin sempitnya luas lahan pertanian yaitu dengan pemanfaatan lahan kering. Kendala utama dalam pemanfaatan lahan kering yaitu bahan organik dan kesehatan tanah rendah. Solusi yang dapat diberikan yaitu dengan pemberian bahan organik. Pemanfaatan lahan kering dapat dilakukan secara berkelanjutan. Adapun Inovasi yang dapat diberikan yaitu dengan menerapkan sistem tanam tumpangsari antara kedelai dan ubi jalar dengan mengatur baris tanaman. Penelitian ini dilakukan pada tanggal 14 Mei - 2 September 2017 di Daerah Antirogo Kabupaten Jember, menggunakan split plot dengan main plot (jumlah 1 baris (B1) dan 2 baris (B2)) dan sub plot (Dosis pupuk organik D0 0 kg/petak, D1 3,2 kg/petak D2 4,8 kg/petak, D3 6,4 kg/petak, dan D4 $8 \mathrm{~kg} /$ petak). Data penelitian dianalisis menggunakan analisis ragam dan apabila terdapat hasil yang berbeda nyata, maka dilakukan uji lanjut menggunakan Duncan pada taraf 5\%. Untuk mengetahui adanya keuntungan ataupun kerugian dalam tanaman tumpangsari dapat dilakukan dengan menggunakan NKL. Hasil penelitian menunjukkan interaksi baris tanam kedelai dengan dosis pupuk organik berpengaruh terhadap produksi pada variabel berat umbi $>150$ g. Perlakuan pemberian dosis pupuk organik berpengaruh terhadap pertumbuhan dan hasil pada variabel panjang sulur, berat segar tanaman, berat kering tanaman, jumlah umbi per tanaman, berat segar umbi per tanaman, dan berat segar umbi perpetak pada ubi jalar dan tinggi tanaman, jumlah polong hampa, berat biji kering per tanaman dan berat kering biji per petak pada kedelai. Faktor baris tanam berpengaruh tidak nyata terhadap pertumbuhan dan hasil ubi jalar-kedelai pada sistem tumpangsari.
\end{abstract}

Kata Kunci: Jumlah Baris, Tumpangsari, Pupuk Organik, Ubi Jalar, Kedelai

\section{ABSTRACT}

One alternative that can be applied to increase the potential of crop production in order to meet the needs of food due to the increasingly narrow area of agricultural land is the use of dry land. The main obstacles in the utilization of 
dry land that is organic material and low soil health. The solution that can be given is by giving organic material. Utilization of dry land can be done in a sustainable manner. The Innovation that can be given is by applying cropping system intercropping between soybeans and sweet potatoes by arranging the line of plants. This research was conducted on May 14 - September 2, 2017 in Antirogo Region Jember Regency, using split plot with main plot (number 1 row (B1) and 2 row (B2)) and sub plot (Dose of organic fertilizer D0 $0 \mathrm{~kg} /$ plot, D1 $3.2 \mathrm{~kg} /$ plot D2 4.8 $\mathrm{kg}$ / plot, D3 $6.4 \mathrm{~kg} /$ plot, and D4 $8 \mathrm{~kg}$ / plot). Research data were analyzed using variance analysis and if there were significantly different result, then continued test using Duncan at 5\% level. To know the existence of profit or loss in intercropping plants can be done by using NKL

The results showed the interaction of soybean cropping line with the dose of organic fertilizer affect the production on tuber weight variables $>150 \mathrm{~g}$. The treatment of organic fertilizer dosage has an effect on growth and yield on variable length of spiraling, fresh weight of plant, dry weight of plant, number of tuber crop, fresh weight of tuber crop, and fresh weight plant tuber on sweet potatoes and plant height, number of empty pods, dry seed weight of planting and dry weight of seeds on soybeans. Planting line factors have nosignificant effect on growth and yield of soybean-sweet potato in intercropping system.

Key words: Number of Rows, Intercropping, Organic Fertilizer, Sweet Potato, Soybean

\section{PENDAHULUAN}

Seiring dengan peningkatan jumlah penduduk, kebutuhan lahan non pertanian meningkat, dampaknya produksi bahan pangan strategis (kedelai) mengalami penurunan dengan tingkat konsumsi yang terus naik (Setiawan, 2016). Meningkatnya konsumsi kedelai tidak diikuti dengan meningkatnya produksi kedelai. Pada tahun 2016 produksi domestik kedelai hanya sebesar 887,54 ribu ton. Produksi tersebut hanya mampu memenuhi $25 \%$ dari konsumsi domestik sehingga terdapat kelebihan permintaan 1,8 juta ton/tahun yang harus impor (Pusat Data dan Sistem Informasi Pertanian, 2016). Hal ini disebabkan karena semakin sempit luas lahan pertanian yang produktif sebagai akibat adanya alih fungsi lahan seperti konversi lahan sawah. Alih fungsi lahan sawah di Indonesia pada tahun 2003-2014 mencapai rata-rata 7.968.696 per tahun (BPS, 2016). Salah satu alternatif yang dapat diterapkan dalam meningkatkan potensi produksi tanaman dalam rangka memenuhi kebutuhan pangan yaitu dengan pendayagunaan lahan kering. Mulyani dan Syarwani (2013) dalam Haryono (2014) potensi lahan kering di Indonesia 
mencapai 122.047.924 ha, dari potensi tersebut yang dapat digunakan untuk usaha pertanian hanya 70.409.742 ha (Mulyani dan Syarwani, 2013) dalam (Haryono, 2014). Pemanfaatan lahan kering dapat dilakukan secara berkelanjutan yaitu menggunakan organic farming dengan menerapkan pemberian pupuk organik dan penggunaan sistem pertanian dengan pola tumpangsari.

Pupuk organik memiliki fungsi utama yaitu mampu memperbaiki sifat biologi, fisika dan kimia (Dewanto dkk., 2015). Pupuk organik penting dilakukan untuk menjaga kesehatan tanah yang berpengaruh terhadap mikroorganisme tanah dan berpengaruh terhadap produksi ubi jalar (Susanto dkk., 2014). Salah satu mikroba yang menguntungkan bagi tanaman adalah Rhizhobium. Mikroba jenis ini mampu bersimbiosis dengan tanaman legum, salah satunya yaitu tanaman kedelai. Tanaman kedelai memiliki akar tunggang yang mampu bersimbiosis dengan rhizhobium (Adisarwanto, 2014). Sari dan Prayudyaningsih (2015) rhizhobium hanya dapat menfiksasi $\mathrm{N}_{2}$ jika berada didalam bintil akar dari mitra legumnya. Apabila kebutuhan N pada tanaman kedelai tercukupi maka Rhizhoium tidak aktif dan fiksasi $\mathrm{N}$ akan berhenti.

Tumpangsari merupakan salah satu sistem pertanaman ganda yang terdapat dua atau lebih jenis tanaman berbeda dan ditanam secara bersamaan dalam waktu yang relatif sama atau berbeda dengan cara penanaman selang-seling serta jarak teratur pada sebidang lahan yang sama (Rastono dkk., 2015). Salah satu tanaman non legum yang akan ditumpangsarikan dengan tanaman kedelai yaitu tanaman ubi jalar. Kebutuhan ubi jalar di Indonesia di proyeksikan terus meningkat. Berdasarkan hasil proyeksi Pusat Data dan Sistem Informasi Pertanian (2016) permintaan ubi jalar pada tahun 2017-2020 akan mengalami peningkatan rata-rata sebesar 4,55\% per tahun dengan jumlah konsumsi 1.031 .576 ton pada tahun 2017 dan mencapai 1.174.947 ton pada tahun 2020 dengan produksi rata-rata 194,565 ton. Peningkatan kebutuhan ubi jalar harus diiringi dengan peningkatan produksinya. Namun demikian pengembangan ubi jalar di Indonesia belum sesuai dengan yang diharapkan dan belum mendapatkan perhatian, sebagaimana tercermin dari luas tanam yang fluktuatif dengan produktivitas yang baru mencapai 9,5 ton umbi/ ha. Sedangkan di tingkat penelitian ubi jalar mampu memberikan hasil hingga 40 ton/ha (Jaya, 2013). Adapun tujuan dilakukan tumpangsari kedelai-ubi 
jalar yaitu tanaman kedelai dapat memasok $\mathrm{N}$ kedalam tanah melalui akar sehingga dapat diserap oleh tanaman ubi jalar. Rhizobium diduga akan menginfeksi akar ubi jalar dan membantu menfiksasi $\mathrm{N}_{2}$ dari udara. Purwaningsih (2009) terdapat populasi bakteri rhizobium $115.10^{5} \mathrm{CFU} / \mathrm{g}$ tanah pada perakaran tanaman ubi jalar.

Berdasarkan uraian diatas, penanaman dengan sistem tumpangsari dapat menciptakan lingkungan yang beragam, sehingga perlu adanya perhatian dalam mengkombinasikan tanaman yang tepat sebagai tanaman kedua dalam meminimalisir kompetisi seperti penyinaran matahari. Salah satu yang dapat dilakukan untuk meminimalisir kompetisi tersebut yaitu dengan mengatur baris tanaman. Pengaturan baris tanaman kedelai tunggal ke baris ganda akan menambah ruang terbuka bagi tanaman ubi jalar sebagai tanaman sela. Penambahan ruang tersebut dapat mengakibatkan bertambahnya radiasi surya ke organ daun ubi jalar atau menambah tangkapan radiasi surya ke organ daun, sehingga dapat menambah hasil ubi jalar. Pengaturan baris tanaman dan jarak tanam juga dapat memberikan dampak positif lainnya seperti menghindari terjadinya tumpang tindih diantara tajuk tanaman dan memberikan ruang bagi perkembangan akar (Muyassir, 2012). Oleh karena itu, pada penelitian ini akan diteliti lebih lanjut mengenai pengaruh jumlah baris kedelai dan dosis pupuk organik terhadap pertumbuhan dan hasil ubi jalar pada sistem tumpangsari ubi jalar-kedelai.

\section{METODE PENELITIAN}

Penelitian dilaksanakan di Desa Antirogo Kabupaten Jember, dimulai pada tanggal 14 Mei sampai dengan 2 September 2017. Analisis tanah dan pupuk organik dilaksanakan di Laboratorium Pusat Penelitian Kopi dan Kakao pada Tanggal 2 April 2017.

Alat yang digunakan dalam penelitian ini yaitu cangkul, meteran, arit, tugal, timbangan, alat tulis, gembor, alat penunjang untuk analisis tanah, dan alat pengukur lainnya. Bahan yang digunakan dalam penelitian ini yaitu bibit stek ubi jalar Varietas Sari, benih kedelai Varietas Detam 1, pupuk organik (C/N 16,69 \%), Urea (N 46\%), KCL (60\%) dan SP-36 (36\%).

Rancangan percobaan yang digunakan dalam penelitian ini yaitu menggunakan Split Plot Design (Rancangan Petak Terbagi) dengan pola dasar 
Rancangan Acak Kelompok (RAK) yang terdiri dari 2 faktor yaitu 2 level pengaturan jumlah baris sebagai petak utama (main plot) (Pengaturan juumlah 1 baris kedelai dan pengaturan jumlah 2 baris kedelai) dan 5 taraf dosis pupuk sebagai anak petak (sub plot) (D0 pupuk organik 0 ton/ha atau $0 \mathrm{~kg} /$ petak, D1 Pupuk organik 10 ton/ha atau 3,2 kg/petak, D2 Pupuk organik 15 ton/ha atau 4,8 kg/petak, D3 Pupuk organik 20 ton/ha atau 6,4 kg/petak dan D4 Pupuk organik 25 ton/ha atau 8 $\mathrm{kg} /$ petak) yang diulang sebanyak $3 \mathrm{kali}$, jadi terdapat $2 \times 5 \times 3$ petak $=30$ petak . Data hasil pengamatan dianalisis menggunakan analisis ragam dan apabila terdapat hasil yang berbeda nyata, maka dilakukan uji lanjut dengan menggunakan Uji Jarak Berganda Duncan (UJD) dengan taraf 5\%.

Penanaman kedelai dalam satu petak dengan ubi jalar dengan jarak $20 \mathrm{~cm}$ x $25 \mathrm{~cm}$, jarak tanam ubi jalar pada 1 baris kedelai $40 \mathrm{~cm}$ x $25 \mathrm{~cm}$ dan jarak tanam ubi jalar pada 2 baris kedelai $60 \mathrm{~cm}$ x $25 \mathrm{~cm}$, sehingga dalam 1 petak dengan pengaturan jumlah 1 baris populasi kedelai sebanyak 25 tanaman dan populasi ubi jalar sebanyak 20 tanaman, sedangkan 1 petak dengan pengaturan jumlah 2 baris populasi kedelai sebanyak 30 dan populasi ubi jalar sebanyak 15 tanaman. Setiap lubang di tanami sebanyak 1 bibit stek untuk tanaman ubi jalar dan 3 benih untuk tanaman kedelai. Penanaman dilakukan dengan mendahulukan tanaman ubi jalar secara serempak sedangkan tanaman kedelai ditaman pada saat 1 MST ubi jalar. Lubang tanam ubi jalar dan kedelai dibuat secara tugal dengan kedalaman 3-5 cm. Penanaman monokultur dilakukan dengan menyesuaikan populasi pada masingmasing tanaman dalam setiap petakan perlakuan tumpangsari.

Variabel pengamatan ubi jalar yaitu panjang sulur, berat segar tanaman, berat kering tanaman, jumlah umbi per tanaman, berat segar umbi per tanaman, berat segar umbi <150 g, berat segar umbi >150 g, berat segar umbi per petak. Variabel pengamatan Kedelai yaitu tinggi tanaman, jumlah polong isi, jumlah polong hampa, berat kering biji per tanaman, berat kering 100 biji, berat kering biji per petak.

\section{HASIL DAN PEMBAHASAN}


Rangkuman nilai F-hitung dari perlakuan jumlah baris kedelai dan dosis pupuk organik disajikan pada Tabel 1 sebagai berikut:

Tabel 1. Rangkuman Nilai F-Hitung Pada Semua Variabel Pengamatan

\begin{tabular}{llccc}
\hline No & Variabel Pengamatan & \multicolumn{3}{c}{ F-hitung } \\
\cline { 3 - 5 } & & $\begin{array}{c}\text { Jumlah Baris } \\
\text { Kedelai } \\
(\mathrm{B})\end{array}$ & $\begin{array}{c}\text { Dosis Pupuk } \\
\text { Organik } \\
(\mathrm{D})\end{array}$ & $\begin{array}{c}\text { Interaksi } \\
\text { B x D }\end{array}$ \\
\hline A & Ubi Jalar & $0,26^{\text {tn }}$ & $5,08^{* *}$ & $2,14^{\text {tn }}$ \\
1 & Panjang sulur & $15,17^{\text {tn }}$ & $5,05^{* *}$ & $0,73^{\text {tn }}$ \\
2 & Berat segar tanaman & $0,95^{\text {tn }}$ & $6,59^{* *}$ & $1,08^{\text {tn }}$ \\
3 & Berat kering tanaman & $0,92^{\text {tn }}$ & $5,27^{* *}$ & $0,6^{\text {tn }}$ \\
4 & Jumlah umbi per tanaman & $1,12^{\text {tn }}$ & $5,33^{* *}$ & $1,26^{\text {tn }}$ \\
5 & Berat segar umbi per tanaman & $4,14^{\text {tn }}$ & $1,75^{\text {tn }}$ & $0,27^{\text {tn }}$ \\
6 & Berat segar umbi <150 & $0,14^{\text {tn }}$ & $3,41^{*}$ & $3,16^{*}$ \\
7 & Berat segar umbi >150 & $7,68^{\text {tn }}$ & $4,92^{* *}$ & $0,52^{\text {tn }}$ \\
8 & Berat segar umbi per petak & & & \\
B & Kedelai & $0,26^{\text {tn }}$ & $5,06^{* *}$ & $1,87^{\text {tn }}$ \\
1 & Tinggi tanaman & $6,74^{\text {tn }}$ & $4,68^{*}$ & $0,27^{\text {tn }}$ \\
2 & Jumlah polong isi & $0,44^{\text {tn }}$ & $13,94^{* *}$ & $0,13^{\text {tn }}$ \\
3 & Jumlah polong hampa & $3,37^{\text {tn }}$ & $5,47^{* *}$ & $0,28^{\text {tn }}$ \\
4 & Berat kering biji per tanaman & $6,25^{\text {tn }}$ & $0,63^{\text {tn }}$ & $1,21^{\text {tn }}$ \\
5 & Berat kering 100 biji & $16,86^{\text {tn }}$ & $4,84^{* *}$ & $0,36^{\text {tn }}$ \\
6 & Berat kering biji per petak &
\end{tabular}

Keterangan : * Berbeda nyata, ** Berbeda sangat nyata, ${ }^{\text {tn }}$ Berbeda tidak nyata

Berdasarkan hasil rangkuman sidik ragam (Tabel 1) menunjukkan bahwa interaksi antara jumlah baris kedelai dengan dosis pupuk organik umumnya berbeda tidak nyata terhadap semua variabel pengamatan kecuali yaitu pada variabel pengamatan berat segar umbi $>150$. Perlakuan jumlah baris kedelai menunjukkan hasil berbeda tidak nyata terhadap semua variabel pengamatan ubi jalar dan kedelai, sedangkan perlakuan dosis pupuk organik menunjukkan hasil berbeda sangat nyata pada variabel pengamatan ubi jalar yaitu panjang sulur, berat segar tanaman, berat kering tanaman, jumlah umbi per tanaman, berat segar umbi pertanaman, berat segar umbi perpetak dan berbeda nyata pada variabel pengamatan berat $>150$ serta berbeda tidak nyata pada variabel pengamatan berat segar $<150$. Perlakuan dosis pupuk organik menunjukkan hasil berbeda sangat nyata pada variabel pengamatan kedelai yaitu tinggi tanaman, jumlah polong hampa, berat kering biji pertanaman, berat kering biji perpetak dan berbeda nyata pada variabel pengamatan jumlah 
polong isi serta berbeda tidak nyata pada variabel pengamatan berat kering 100 biji.

Pengaruh Interaksi Jumlah Baris Kedelai (B) dan Pupuk Organik (D) terhadap Pertumbuhan dan Hasil Ubi Jalar pada Sistem Tumpangsari Ubi Jalar-Kedelai

Berdasarkan hasil penelitian yang dilakukan pada (Tabel 1) pengaruh interaksi jumlah baris kedelai (B) dan pupuk organik (D) terhadap pertumbuhan dan hasil ubi jalar pada sistem tumpangsari ubi jalar-kedelai menunjukkan hasil berbeda nyata terhadap variabel berat umbi segar $>150$, sedangkan pada variabel pengamatan lainnya menunjukkan hasil berbeda tidak nyata. Hal tersebut dapat dikarenakan variabel pengamatan yang dilakukan dipengaruhi oleh faktor tunggal dan dapat juga dipengaruhi oleh faktor lingkungan yang kurang mendukung dalam pertumbuhan dan hasil tanaman, sedangkan pada berat umbi segar >150 faktor jumlah baris kedelai dan pupuk organik saling mempengaruhi sehingga menunjukkan hasil berbeda nyata.

\section{Berat Segar Umbi $>150$}

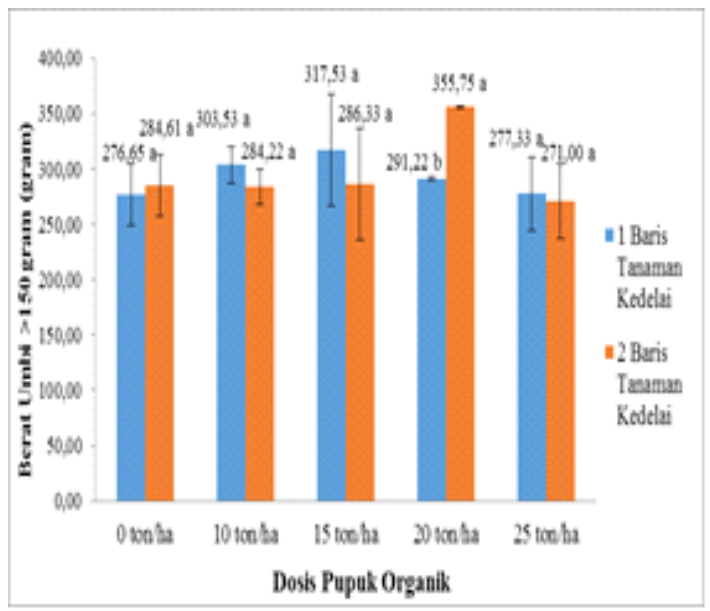

Gambar 1: Pengaruh Sederhana umlah Baris Tanam Kedelai Terhadap Dosis Pupuk Organik yang Sama Pada Berat Segar Umbi $>150$ g (Duncan $\alpha=5 \%$ ) 


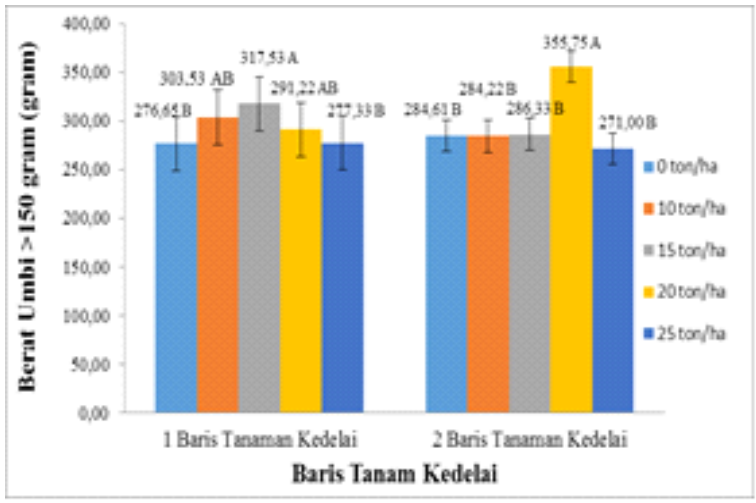

Gambar 2: Pengaruh Sederhana Dosis Pupuk Organik terhadap Jumlah Baris Tanam Kedelai yang Sama Pada Berat Segar umbi $>150 \mathrm{~g}$ (Duncan $\alpha=5 \%$ )

Berdasarkan hasil uji duncan 5\% pada (Gambar 1) pengaruh sederhana perlakuan jumlah baris kedelai pada taraf D0 yang sama menunjukkan hasil yang berbeda tidak nyata terhadap berat segar umbi >150 yaitu B1D0 dengan hasil lebih kecil (276,6 g) dibandingkan B2D0 dengan hasil lebih besar (284,6 g). Rekomendasi yang dapat diberikan untuk mendapatkan hasil terbaik yaitu menggunakan B2D0 dengan hasil terbaik 276,6 g.

Berdasarkan hasil uji duncan 5\% pada (Gambar 1) pengaruh sederhana perlakuan jumlah baris kedelai pada taraf D1 yang sama menunjukkan hasil yang berbeda tidak nyata terhadap berat segar umbi >150 yaitu B1D1 dengan hasil lebih besar (303,5 g) dibandingkan B2D1 dengan hasil lebih kecil (284,2 g). Rekomendasi yang dapat diberikan untuk mendapatkan hasil terbaik yaitu menggunakan B1D1 dengan hasil terbaik 303,5 g.

Berdasarkan hasil uji duncan 5\% pada (Gambar 1) pengaruh sederhana perlakuan jumlah baris kedelai pada taraf D2 yang sama menunjukkan hasil yang berbeda tidak nyata terhadap berat segar umbi >150 yaitu B1D2 dengan hasil lebih besar (317,5 g) dibandingkan B2D2 dengan hasil lebih kecil (291,2 g). Rekomendasi yang dapat diberikan untuk mendapatkan hasil terbaik yaitu menggunakan B1D2 dengan hasil terbaik 317,5 g.

Berdasarkan hasil uji duncan 5\% pada (Gambar 1) pengaruh sederhana perlakuan jumlah baris kedelai pada taraf D3 yang sama menunjukkan hasil yang berbeda nyata terhadap berat segar umbi >150 yaitu B1D3 dengan hasil lebih kecil (291,2 g) dibandingkan B2D3 dengan hasil lebih besar (355,7 g). Rekomendasi yang dapat diberikan untuk mendapatkan hasil terbaik yaitu menggunakan B2D3 
dengan hasil terbaik 355,7 g.

Berdasarkan hasil uji duncan 5\% pada (Gambar 1) pengaruh sederhana perlakuan jumlah baris kedelai pada taraf D4 yang sama menunjukkan hasil yang berbeda tidak nyata terhadap berat segar umbi >150 yaitu B1D4 dengan hasil lebih besar (277,3 g) dibandingkan B2D4 dengan hasil lebih kecil (271 g). Rekomendasi yang dapat diberikan untuk mendapatkan hasil terbaik yaitu menggunakan B1D4 dengan hasil terbaik $277,3 \mathrm{~g}$.

Berdasarkan hasil uji duncan 5\% pada (Gambar 2) pengaruh sederhana perlakuan dosis pupuk organik pada taraf jumlah baris kedelai (B1 yang sama) terhadap berat segar umbi >150 menunjukkan bahwa berat segar umbi >150 yang terbaik diperoleh B1D2 yaitu $(317,5 \mathrm{~g})$ dengan dosis 15 ton/ha sedangkan hasil terkecil diperoleh B1D0 yaitu (276,6 g) dengan dosis 0 ton/ha atau kontrol yang berbeda tidak nyata dengan berat segar umbi >150 pada B1D4 (dosis 25 ton/ha) yaitu 277,3 g).

Berdasarkan hasil uji duncan 5\% pada (Gambar 2) pengaruh sederhana perlakuan dosis pupuk organik pada taraf jumlah baris kedelai (B2 yang sama) terhadap berat segar umbi $>150$ menunjukkan bahwa berat segar umbi $>150$ yang terbaik diperoleh B2D3 yaitu (355,7 g) dengan dosis 20 ton/ha yang berbeda nyata dengan perlakuan B2D0 (284,6 g), B2D1 (284,2 g), B2D2 (286,3) dan B2D4 (271 g), sedangkan hasil berat segar umbi >150 terkecil diperoleh D4 (271 g) yang berbeda tidak nyata dengan perlakuan B2D0 (284,6 g), B2D1 (284,2 g) dan B2D2 $(286,3 \mathrm{~g})$.

Berat umbi erat kaitannya dengan jumlah umbi yang dapat dipasarkan dan memiliki korelasi positif terhadap dua variabel tersebut, sehingga menghasilkan bobot >150 g. Menurut Salisbury dan Ross (1992) dalam Ghozali dkk., (2015) menyatakan bahwa perlakuan kombinasi yang memiliki bobot umbi yang dapat dipasarkan tertinggi atau terendah sama dengan perlakuan kombinasi jumlah umbi yang dapat dipasarkan, sehingga dapat disimpulkan sementara dengan adanya korelasi positif antara berat umbi dan jumlah umbi yang dapat dipasarkan. Jumlah umbi yang dapat dipasarkan tergantung pada berat umbi yang dapat dipasarkan. Hasil umbi merupakan perpaduan antar faktor genetik dan lingkungan. 


\section{Pengaruh Jumlah Baris Kedelai (B) terhadap Pertumbuhan dan Hasil Ubi Jalar pada Sistem Tumpangsari Ubi Jalar-Kedelai}

Berdasarkan hasil penelitian yang dilakukan pada (Tabel 1) pengaruh utama perlakuan jumlah baris kedelai (B) terhadap pertumbuhan dan hasil ubi jalar pada sistem tumpangsari ubi jalar-kedelai menunjukkan hasil berbeda tidak nyata terhadap semua variabel pengamatan pertumbuhan dan hasil ubi jalar dan kedelai. Hal ini dapat dikarenakan ukuran jarak tanam dalam jumlah baris tanam kedelai yang dicoba tidak menyebabkan adanya kompetisi antar tanaman karena diduga kebutuhan unsur hara, air dan faktor tumbuh lainnya seperti cahaya masih terpenuhi (Fajrin dkk., 2015). Lebih lanjut Salisbury dan Ross (1992) dalam Ghozali dkk., (2015) menyatakan bahwa kerapatan atau jumlah populasi yang optimal serta teratur dalam suatu lahan pada dasarnya dapat memberikan kemungkinan bagi tanaman untuk tumbuh baik tanpa mengalami persaingan dalam penerimaan intensitas sinar, penyerapan air dan hara sehingga penyerapan hara akan efektif.

\section{Pengaruh Dosis Pupuk Organik terhadap Pertumbuhan dan Hasil Ubi Jalar dalam Sistem Tumpangsari Ubi Jalar-Kedelai}

\section{Panjang Sulur Ubi Jalar (cm)}

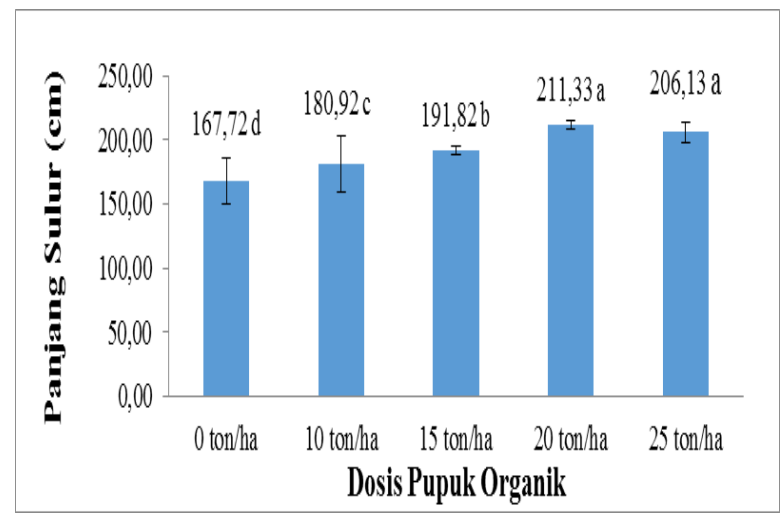

Gambar 3: Pengaruh Dosis Pupuk Organik Terhadap Pnjang Sulur (cm)

Berdasarkan hasil uji jarak berganda Duncan (Gambar 3) pengaruh utama faktor dosis pupuk organik terhadap panjang sulur menunjukkan bahwa panjang sulur terpanjang dihasilkan oleh dosis pupuk organik D3 (dosis pupuk organik 20 ton/ha) yaitu dengan panjang $211,33 \mathrm{~cm}$ dan berbeda tidak nyata dengan D4 (dosis pupuk organik 25 ton/ha) yaitu $206,13 \mathrm{~cm}$ tetapi berbeda nyata D0 $(167,72 \mathrm{~cm})$, D1 
$(180,92 \mathrm{~cm})$ dan D2 $(191,82 \mathrm{~cm})$, sedangkan panjang sulur terpendek yaitu dihasilkan oleh D0 (dosis 0 ton/ha) dengan panjang 167,72 cm.

Hal tersebut dapat dikarenakan terdapat penambahan pupuk KCL yang tidak merata pada saat tanaman ubi jalar berumur 1 minggu akibat permukaan daun ubi jalar menguning seperti terkena virus, selain itu pupuk organik yang digunakan telah terdekomposisi secara sempurna. Dosis pupuk organik yang diberikan sebanyak 20 ton/ha menyediakan unsur $\mathrm{N}$ sebanyak $584 \mathrm{~kg} / \mathrm{ha}$ dalam tanah dapat mencukupi $\mathrm{N}$ sebanyak $150 \mathrm{~kg} / \mathrm{ha}$ yang dibutuhkan tanaman ubi jalar dalam pertumbuhan vegetatif, sehingga dapat meningkatkan pertumbuhan ubi jalar. Hal tersebut sesuai dengan pendapat Rosmarkam dan Nasih (2002) pupuk organik yang matang dekomposisinya, jika diberikan ke tanaman dapat memperbaiki pertumbuhan vegetatif. Rachman dkk., (2008) menyatakan bahwa pemberian bahan organik mampu memberikan konstribusi ketersediaan unsur hara $\mathrm{N}, \mathrm{P}$, dan $\mathrm{K}$ bagi tanaman, sehingga ketersediaan unsur hara dalam tanah yang diperlukan oleh tanaman menjadi tercukupi serta dapat mendukung dalam proses pertumbuhan panjang sulur ubi jalar.

\section{Berat Segar Tanaman $(g)$}

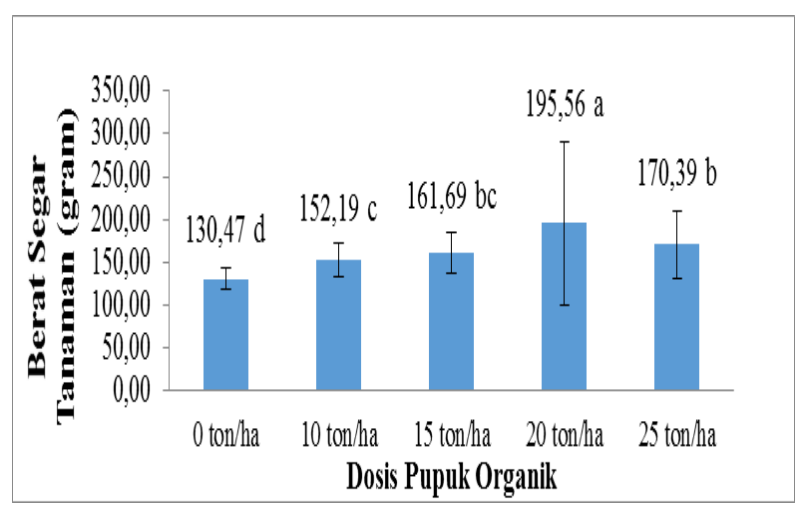

Gambar 4: Pengaruh Dosis Pupuk Organik Terhadap Berat Segar Tanaman (g)

Berdasarkan hasil uji jarak berganda Duncan (Gambar 4) pengaruh utama faktor dosis pupuk organik terhadap berat segar tanaman menunjukkan bahwa berat segar tanaman tertinggi dihasilkan oleh dosis pupuk organik D3 (dosis pupuk organik 20 ton/ha) yaitu dengan 195,96 g dan berbeda nyata terhadap semua perlakuan, sedangkan hasil terendah diperoleh pada perlakuan D0 (dosis 0 ton/ha) 
yaitu 130,47 g. Pengukuran berat segar tanaman dilakukan untuk mengetahui aktivitas metabolisme tanaman (Salisbury dan Ross, 1992). Menurut Yelianti dkk., (2008) menyatakan bahwa dengan pemberian pupuk organik ke dalam tanah mampu memperbaiki struktur tanah menjadi gembur, sehingga sistem perakaran dapat berkembang lebih baik dan proses penyerapan unsur hara berjalan lebih optimal.

\section{Berat Kering Tanaman (g)}

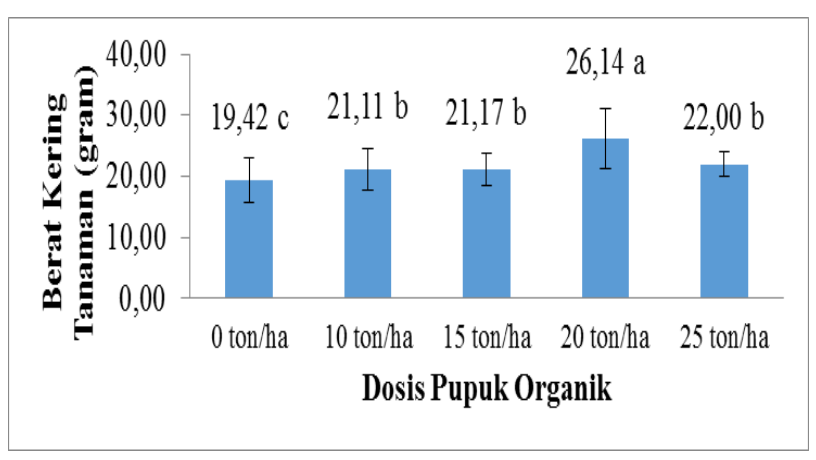

Gambar 5: Pengaruh Dosis Pupuk Organik Terhadap Berat Kering Tanaman (g)

Berdasarkan hasil uji jarak berganda Duncan (Gambar 5) pengaruh utama faktor dosis pupuk organik terhadap berat kering tanaman menunjukkan bahwa berat kering tanaman tertinggi dihasilkan oleh dosis pupuk organik D3 (dosis 20 ton/ha) yaitu dengan 26,14 g dan berbeda nyata terhadap semua perlakuan, sedangkan hasil terendah diperoleh pada perlakuan D0 (dosis 0 ton/ha) yaitu 19,72 g. Hal tersebut dapat dikarenakan pemberian pupuk organik dengan dosis 20 ton/ha menambah unsur $\mathrm{N}$ dalam tanah yang dibutuhkan tanaman ubi jalar dalam pertumbuhan vegetatif, sehingga dapat meningkatkan pertumbuhan ubi jalar. Hal ini didukung dengan pendapat Permanasari dan Kastono (2012) pada keadaan tersebut tanaman mampu mengabsorbsi energi matahari yang digunakan dalam proses fotosintesis lebih baik serta mampu memanfaatkannya dengan cara efisien, sehingga berat kering yang dihasilkan lebih besar. Lebih lanjut dijelaskan oleh Zuchri (2012) yang menyatakan bahwa semakin baik pertumbuhan tanaman dan semakin banyak unsur hara serta air yang terserap maka bobot kering tanaman semakin berat. 


\section{Jumlah Umbi Per Tanaman (Buah)}

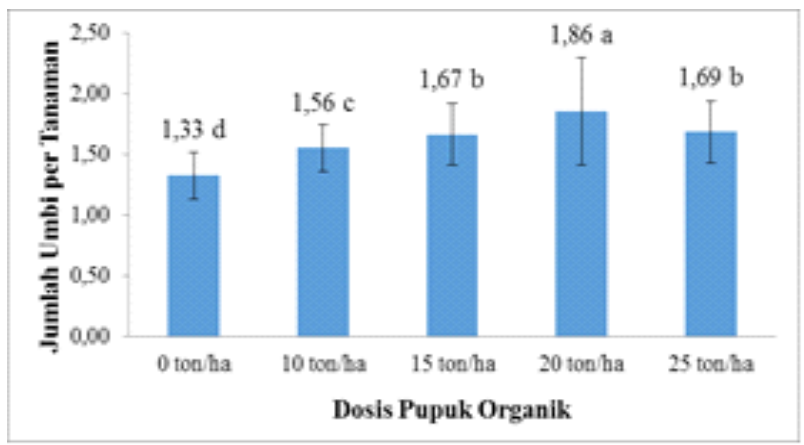

Gambar 6: Pengaruh Dosis Pupuk Organik Terhadap Jumlah Umbi Per Tanaman (Buah)

Berdasarkan hasil uji jarak berganda Duncan (Gambar 6) pengaruh utama faktor dosis pupuk organik terhadap jumlah umbi per tanaman menunjukkan bahwa jumlah umbi per tanaman terbanyak dihasilkan oleh dosis pupuk organik D3 (dosis pupuk organik 20 ton/ha) yaitu dengan 1,86 buah dan berbeda nyata terhadap semua perlakuan, sedangkan hasil terendah diperoleh pada perlakuan D0 (dosis 0 ton/ha) yaitu 1,33 buah. Hasil tersebut mengindikasikan bahwa dosis pupuk organik yang deberikan pada D3 yaitu dosis 20 ton/ha lebih optimum dan ketersediaan hara makro seperti $\mathrm{P}$ dan $\mathrm{K}$ yang dibutuhkan untuk pembentukan umbi tercukupi dan seimbang serta tidak berlebih, sehingga menghasilkan jumlah umbi segar per tanaman lebih banyak. Unsur hara tersebut sangat berperan didalam pembentukan dan pengisian umbi. Hal ini sesuai dengan pendapat Saifuddin Sarief (1995) dalam Lana (2010) menyatakan bahwa unsur hara makro yang berperan didalam pembentukan dan pengisian umbi diantaranya yaitu unsur $\mathrm{P}$ dan $\mathrm{K}$. Menurut Soenyoto (2014) dalam proses pembentukan umbi unsur hara $\mathrm{P}$ berperan dalam memproduksi akar penyimpanan (umbi).

\section{Berat Segar Umbi Per Tanaman}

Umbi merupakan bagian ekonomis yang terdapat pada tanaman ubi jalar. pembentukan umbi sangatlah dipengaruhi oleh banyaknya asimilat yang dihasilkan tanaman. Pembentukan umbi biasanya dimulai dengan perbanyakan sel yang diikuti oleh pembesaran sel. Proses pembentukan umbi membutuhkan energi. Energi tersebut diperoleh tanaman dari unsur hara yang terdapat dalam tanah, sehingga pemupukan dalam hal ini menjadi penting untuk menghasilkan berat umbi yang 
maksimum (Rasada, 1996) dalam (Neltriana, 2015).

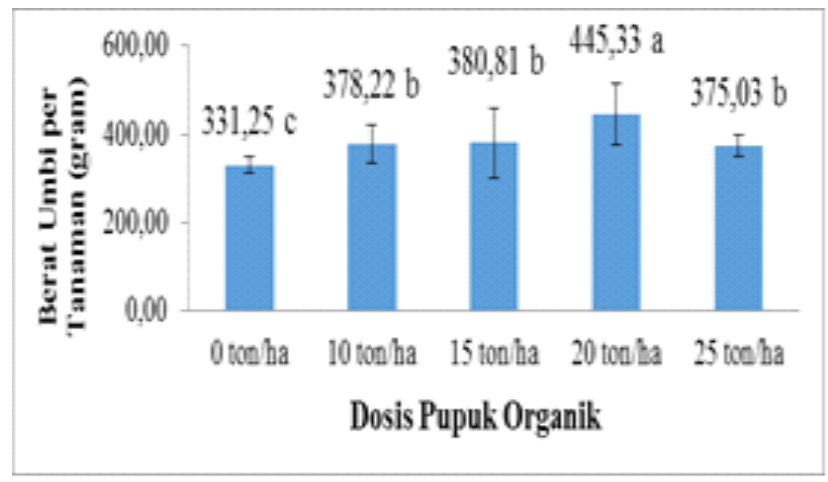

Gambar 7: Pengaruh Dosis Pupuk Organik Terhadap Berat Umbi Per Tanaman (g)

Berdasarkan hasil uji jarak berganda Duncan (Gambar 7) pengaruh utama faktor dosis pupuk organik terhadap berat segar umbi per tanaman menunjukkan bahwa berat segar umbi per tanaman tertinggi dihasilkan oleh dosis pupuk organik D3 (dosis pupuk organik 20 ton/ha) yaitu dengan $445 \mathrm{~g}$ dan berbeda nyata terhadap semua perlakuan, sedangkan hasil terendah diperoleh pada perlakuan D0 (dosis 0 ton/ha) yaitu 331,25 g. Hal tersebut mungkin dikarenakan terdapat pengaruh unsur $\mathrm{P}$ dan $\mathrm{K}$ yang terkandung dalam pupuk organik dengan dosis 20 ton/ha yang mampu memperlihatkan perbedaan hasil ubi jalar dari perlakuan lainnya. Hasil penelitian Paturohman dan Sumarno (2015) juga menjelaskan bahwa pemberian bahan organik dengan dosis 20 ton/ha mampu meningkatkan umbi segar pertanaman.

\section{Berat Segar Umbi Per Petak (g)}

Berat umbi segar per petak merupakan variabel produksi yang penting. Berat umbi segar perpetak didapatkan dari hasil penimbangan seluruh umbi dalam satu petak tanaman ubi jalar. Berdasarkan hasil uji jarak berganda Duncan (Gambar 8) pengaruh utama faktor dosis pupuk organik terhadap berat segar umbi per petak menunjukkan bahwa berat segar umbi per petak tertinggi dihasilkan oleh dosis pupuk organik D3 (dosis pupuk organik 20 ton/ha) yaitu dengan $5068 \mathrm{~g}$ dan berbeda nyata terhadap semua perlakuan. Perlakuan dengan dosis D1 (4540,67 g) menunjukkan hasil berbeda tidak nyata dengan perlakuan D2 $(4727,17 \mathrm{~g})$, sedangkan hasil terendah diperoleh pada perlakuan D0 (dosis 0 ton/ha) yaitu $3593,50 \mathrm{~g}$. 


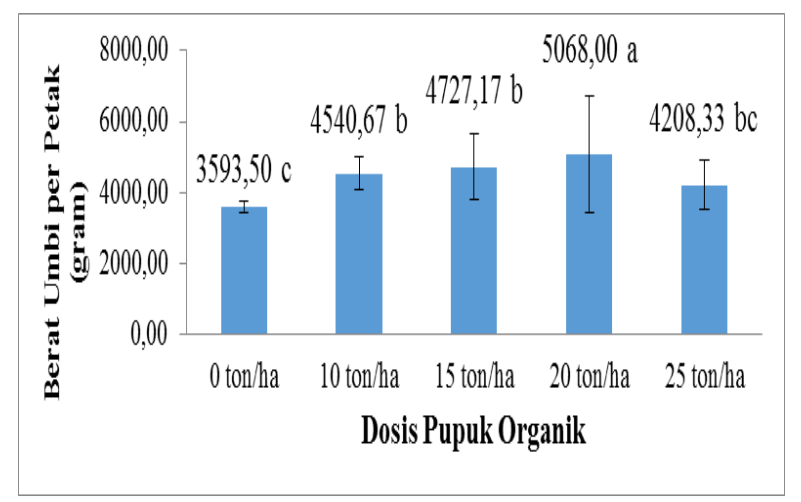

Gambar 8: Pengaruh Dosis Pupuk Organik Terhadap Berat Segar Umbi Per Petak (g)

Hal ini sejalan dengan penelitian yang telah dilakukan oleh Paturohman dan Sumarno (2015) hasil ubi jalar menghasilkan umbi optimal sebesar 20,6 ton/ha yaitu dengan dosis pupuk organik 20 ton/ha, sedangkan pemberian pupuk organik dengan dosis lebih dari 20 lebih ton/ha, mengakibatkan unsur hara yang diserap oleh tanam lebih terkonsentrasikan pada pertumbuhan vegetatif sehingga hasil fotosintesis yang berupa karbohidrat tidak tertranslokasikan dengan baik ke umbi. Hal ini mengakibatkan berat umbi yang dihasilkan justru menurun.

\section{Tinggi Tanaman Kedelai (cm)}

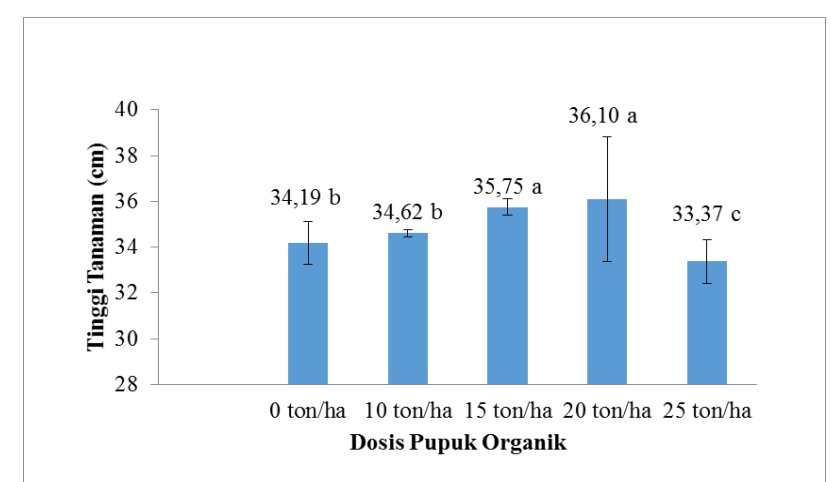

Gambar 9: Pengaruh Dosis Pupuk Organik Terhadap Tinggi Tanaman Kedelai (cm)

Tinggi tanaman merupakan salah satu tolak ukur yang sering digunakan pada awal pertumbuhan sebagai indikator untuk mengetahui pengaruh suatu perlakuan yang diberikan pada tanaman. Berdasarkan hasil uji jarak berganda Duncan (Gambar 9) pengaruh utama faktor dosis pupuk organik terhadap tinggi tanaman kedelai menunjukkan bahwa tinggi tanaman tertinggi dihasilkan oleh dosis 
pupuk organik D3 (dosis pupuk organik 20 ton/ha) yaitu dengan tinggi $36,10 \mathrm{~cm}$ dan berbeda tidak nyata dengan D2 (dosis pupuk organik 15 ton/ha) yaitu $35,75 \mathrm{~cm}$ tetapi berbeda nyata dengan perlakuan D0 (34,19 cm), D1 (24,62 cm) dan D4 (33,37 $\mathrm{cm}$ ), sedangkan tinggi tanaman terpendek yaitu dihasilkan oleh D4 (dosis 25 ton/ha) dengan tinggi $33,37 \mathrm{~cm}$.

Hasil penelitian ini sesuai dengan penelitian Maharam (2017) pemberian pupuk organik sebanyak 20 ton/ha dapat memberikan hasil tertinggi pada tinggi tanaman kedelai. Tinggi tanaman kedelai dapat dikarenakan penggunaan pupuk organik dapat memperbaiki struktur tanah menjadi lebih baik. Lebih lanjut Kartasapoetra (1988) penggunaan pupuk organik mampu memperbaiki tata air dan udara dalam tanah serta memperbaiki sifat kimia tanah, karena adanya absorbsi dan daya tukar kation yang besar sehingga mempengaruhi penyediaan unsur-unsur hara yang dibutuhkan tanaman. Selain itu tanaman kedelai mampu menfiksasi N yang dapat membantu dalam fase vegetatif. Selain itu pupuk organik yang diberikan sebanyak 20 ton/ha menyediakan unsur $\mathrm{N}$ sebanyak $584 \mathrm{~kg} / \mathrm{ha}$ dalam tanah dapat mencukupi $\mathrm{N}$ sebanyak $50 \mathrm{~kg} / \mathrm{ha}$ yang dibutuhkan tanaman kedelai dalam pertumbuhan vegetatif, sehingga dengan pemberian dosis 20 ton/ha (D3) mampu menghasilkan tinggi tanaman terbaik dengan rata-rata 36,1

\section{Jumlah Polong Isi}

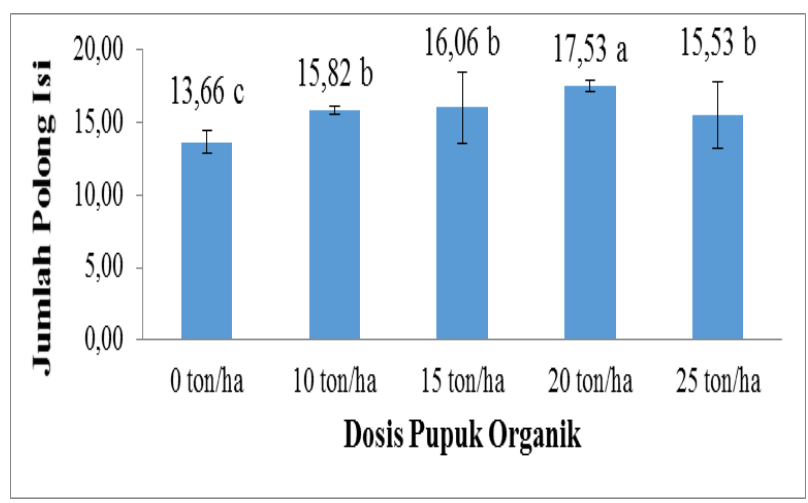

Gambar 10: Pengaruh Dosis Pupuk Organik Terhadap Jumlah Polong Isi

Berdasarkan hasil uji jarak berganda Duncan (Gambar 10) pengaruh utama faktor dosis pupuk organik terhadap jumlah polong isi menunjukkan bahwa jumlah 
polong isi terbaik dihasilkan oleh dosis pupuk organik D3 (dosis pupuk organik 20 ton/ha) yaitu 17,53 dan berbeda nyata terhadap semua perlakuan yang lain, sedangkan hasil terendah diperoleh pada perlakuan D0 (dosis 0 ton/ha) yaitu 13,66. Menurut Rahmi dkk, (2017) jumlah polong erat kaitannya dengan pertumbuhan tanaman di masa vegetatif. Jika pertumbuhan tinggi tanaman bagus, maka akan berpangaruh terhadap jumlah jumlah polong yang dihasilkan.

\section{Jumlah Polong Hampa}

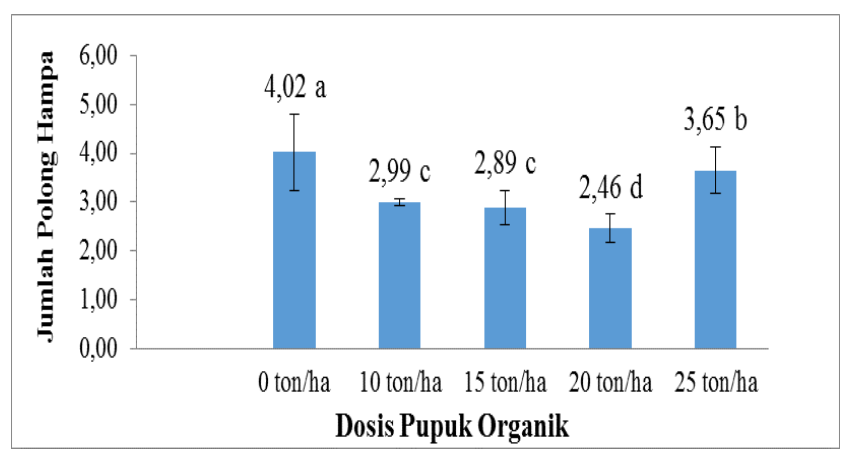

Gambar 11: Pengaru Dosis Pupuk Organik Terhadap Jumlah Polong Hampa

Berdasarkan hasil uji jarak berganda Duncan (Gambar 11) pengaruh utama faktor dosis pupuk organik terhadap jumlah polong hampa menunjukkan bahwa jumlah polong hampa terkecil dihasilkan oleh dosis pupuk organik D3 (dosis pupuk organik 20 ton/ha) yaitu 2,46 dan berbeda nyata terhadap semua perlakuan, sedangkan hasil jumlah polong hampa tertinggi diperoleh pada perlakuan D0 (dosis 0 ton/ha) yaitu 4,02. Lebih lanjut hasil penlitian Samuli dkk, (2012) perlakuan pupuk organik bokashi pada berbagai dosis berpengaruh sangat nyata terhadap jumlah polong hampa total yang terendah. Hal ini mengindikasi pemberian pupuk organik dapat memperbaiki kondisi tanah, sehingga menguntungkan dalam pertumbuhan tanaman terutama pengelolaan bahan organik, meningkatkan kehidupan biologi tanah, optimalisasi ketersediaan dan keseimbangan daur hara melalui fiksasi nitrogen, penyerapan hara

\section{Berat Kering Biji Per Tanaman (g)}




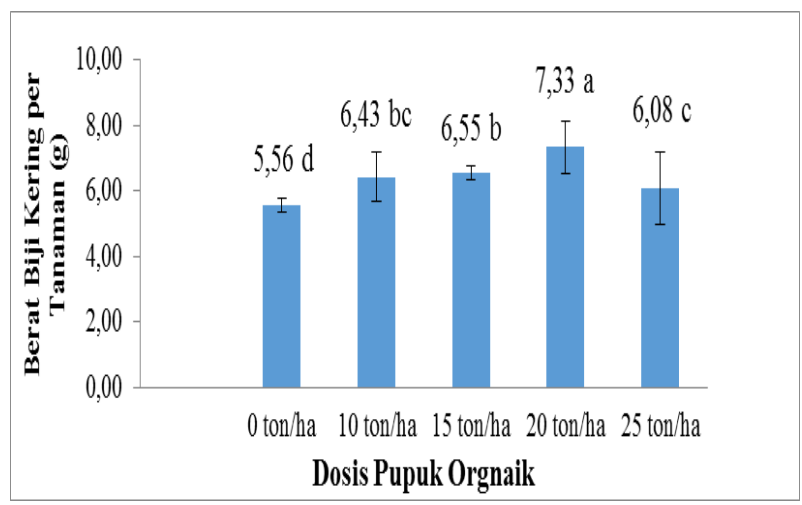

Gambar 12: Pengaruh Dosis Pupuk Organik Terhadap Berat Kering Biji Per Tanaman (g)

Berdasarkan hasil uji jarak berganda Duncan (Gambar 12) pengaruh utama faktor dosis pupuk organik terhadap berat kering biji per tanaman menunjukkan bahwa berat kering biji per tanaman terbaik dihasilkan oleh dosis pupuk organik D3 (dosis pupuk organik 20 ton/ha) yaitu 7,33 g dan berbeda nyata terhadap semua perlakuan, sedangkan hasil terendah diperoleh pada perlakuan D0 (dosis 0 ton/ha) yaitu 5,56 g. Hal ini dapat dikarenakan pemberian pupuk organik yang diberikan mampu menyediakan unsur hara $\mathrm{N}, \mathrm{P}$ dan $\mathrm{K}$ yang tinggi sehingga dapat diserap tanaman dalam jumlah yang cukup. Unsur hara yang terkandung dalam pupuk organik dapat membantu pembentukan biji Lebih lanjut Hardjowigeno (1995) dalam Nurlisan dkk., (2012) unsur N yang terdapat dalam pupuk setelah diserap tanaman merupakan penyusun bahan organik baik di daun maupun di dalam biji sehingga pemberian pupuk yang mengandung $\mathrm{N}$ pada tanaman akan meningkatkan berat kering biji. Selain dari unsur N pupuk organik juga mengandung P yang cukup tinggi, dimana $\mathrm{P}$ adalah faktor penting dalam pertumbuhan bunga, pengisian biji dan membuat biji menjadi lebih bernas, sehingga dengan pemberian $\mathrm{P}$ yang tinggi cenderung meningkatkan hasil biji per tanaman.

\section{Berat Kering Biji Per Petak (g)}

Berdasarkan hasil uji jarak berganda Duncan (Gambar 13) pengaruh utama faktor dosis pupuk organik terhadap berat kering biji per petak menunjukkan bahwa berat kering biji per petak terbaik dihasilkan oleh dosis pupuk organik D3 (dosis pupuk organik 20 ton/ha) yaitu 129,85 g dan berbeda nyata terhadap semua perlakuan yang lain, sedangkan hasil terendah diperoleh pada perlakuan D0 (dosis 
0 ton/ha) yaitu 103,22 g. Hal tersebut dapat dikarenakan terdapat lebih banyak faktor-gaktor pertumbuhan yang diterima oleh tanaman termasuk pemupukan, maka dapat menyebabkan laju fotosintesis meningkat. Meningkatnya laju fotosintesis maka $\mathrm{CO}_{2}$ yang diikat dalam proses fotosintesis tersebut akan lebih banyak dari pada $\mathrm{CO}_{2}$ yang dilepaskan dalam proses respirasi, sehingga asimilat yang dihasilkan lebih berpengaruh terhadap pertumbuhan dan hasil tanaman (Maruapey, 2010).

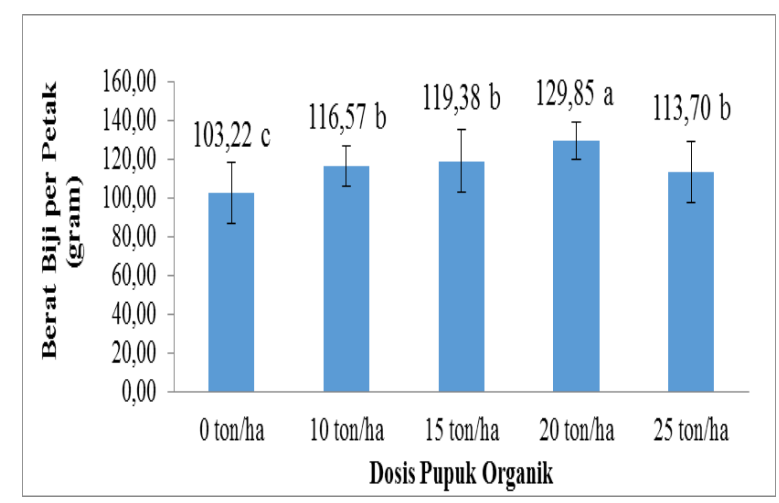

Gambar 13: Pengaruh Dosis Pupuk Organik Terhadap Beat Kering Biji Per Petak (g)

\section{Nilai Kesetaraan Lahan (NKL)}

Berdasarkan hasil perhitungan nilai kesetaraan lahan (NKL) tumpangsari tanaman ubi jalar dengan kedelai (Tabel 2) menunjukkan bahwa perlakuan dengan pola tumpangsari antara ubi jalar dan kedelai dengan menggunakan perlakuan baris tanam kedelai dan dosis pupuk organik, memiliki nilai NKL yang bervariasi. Nilai NKL pada semua perlakuan menunjukkan nilai NKL yang lebih dari satu (>1). Nilai NKL tertinggi yaitu diperoleh hasil sebesar 1,57 pada perlakuan B2D3. Angka tersebut menunjukkan bahwa dengan cara pola tanam tumpangsari, pemanfaatan penggunaan lahan semakin efisien dan produktif dibandingkan dengan pola monokultur. NKL adalah salah satu cara untuk menghitung produktivitas lahan yang ditanam dua atau lebih jenis tanam menggunakan pola tanam tumpangsari. Hal ini sesuai dengan pernyataan Handayani (2011) yang menyatakan bahwa sistem tumpangsari akan lebih menguntungkan dibandingkan dengan sistem monokultur jika NKL lebih besar dari satu (>1). 
Tabel 2 Hasil Nilai Kesetaraan Lahan (NKL) Tumpangsari Tanaman Ubi Jalar dan kedelai

\begin{tabular}{cccccc}
\hline \multirow{2}{*}{ Perlakuan } & \multicolumn{2}{c}{ Hasil Tumpangsari } & \multicolumn{2}{c}{ Hasil Monokultur } & \\
\cline { 2 - 4 } & $\begin{array}{c}\text { Ubi Jalar } \\
(\mathrm{g})\end{array}$ & $\begin{array}{c}\text { Kedelai } \\
(\mathrm{g})\end{array}$ & $\begin{array}{c}\text { Ubi Jalar } \\
(\mathrm{g})\end{array}$ & $\begin{array}{c}\text { Kedelai } \\
(\mathrm{g})\end{array}$ & NKL \\
\hline B1D0 & 3555,67 & 87,53 & 6400 & 186,67 & 1,02 \\
B1D1 & 4310 & 105,2 & & & 1,24 \\
B1D2 & 4186,33 & 106,97 & & & 1,22 \\
B1D3 & 4849,33 & 119,33 & & & 1,40 \\
B1D4 & 3878,67 & 97,23 & & & 1,12 \\
B2D0 & 3631,33 & 118,9 & & 1,20 \\
B2D1 & 4771,33 & 127,93 & & 1,43 \\
B2D2 & 5268 & 131,8 & & 1,52 \\
B2D3 & 5286,67 & 140,37 & & & 1,57 \\
B2D4 & 4538 & 113,7 & & & 1,31 \\
\hline
\end{tabular}

\section{KESIMPULAN}

Berdasarkan penelitian yang telah dilakukan maka dapat disimpulkan bahwa:

1. Jumlah baris tanam dan pupuk organik pada sistem tumpangsari ubi jalarkedelai berbeda nyata terhadap berat segar umbi $>150$ g. Hasil terbaik diperoleh dari kombinasi jumlah 1 baris tanam kedelai dengan dosis 15 ton/ha dan jumlah 2 baris tanam kedelai dengan dosis 20 ton/ha.

2. Jumlah baris tanam pada sistem tumpangsari ubi jalar-kedelai berbeda tidak nyata terhadap semua variabel pertumbuhan dan hasil.

3. Pupuk organik 20 ton/ha berbeda sangat nyata terhadap variabel panjang sulur, jumlah umbi per tanaman, berat segar per tanaman, berat umbi perpetak ubi jalar dan tinggi tanaman, jumlah polong hampa, berat kering biji per tanaman, berat kering biji perpetak kedelai dan berbeda nyata terhadap variabel berat umbi >150 dan jumlah polong isi.

\section{DAFTAR PUSTAKA}

Badan Pusat Statistik. 2016. Data Luas Lahan Sawah Menurut Provinsi (ha), 2003 - 
2014. http://bps.go.id.linkTableDinamis/view/id/. Diakses pada 24 Maret 2017.

Dewanto, F. G., J. J. M. R. Londok, R. A. V. Tuturoong dan W. B. Kaunang. 2013. Pengaruh Pemupukan Anorganik dan Organik Terhadap Produksi Tanaman Jagung Sebagai Sumber Pakan. Zootek, 32(5) : 1-8.

Fajrin A., Sinar S., dan Sucipto. 2015. Respon Tanaman Kedelai Sayur Edamame Terhadap Perbedaan Jenis Pupuk dan Ukuran Jarak Tanam. AGROVIGOR, $8(1): 57-62$.

Ghozali I. M., Gatot S., dan Hidayat B. S. 2015. Pengaruh Beberapa Varietas dan Waktu Tanam Terhadap Pertumbuhan dan Hasil Ubi Jalar pada Sistem Tumpangsari dengan Jagung. Ilmiah Pertanian, $\mathrm{X}(\mathrm{X})$ : 1-5.

Handayani A. 2011. Pengaruh Model Tumpang Sari Terhadap Pertumbuhan Dan Hasil Tanaman Gandum dan Tembakau. Widyariset, 14(3) : 479-488.

Haryono. 2014. Kebijakan Kementerian Pertanian dalam Sistem Pembangunan Pertanian yang Inklusif untuk memajukan petani Lahan Sub Optimal. Seminar Nasional Lahan Suboptimal.

Jaya E. F. P. 2013. Pemanfaatan Antioksidan dan Betakaroten Ubi Jalar Ungu pada Pembuatan Minuman Non-Beralkohol. Media Gizi Masyarakat Indonesia, 2(2) : 54-57.

Kartasapoetra, A. G. 1988. Teknologi Konservasi Tanah dan Air. Bina Aksara. Jakarta.

Lana W. 2010. Pengaruh Dosis Pupuk Kandang Sapi dan Berat Benih Terhadap Pertumbuhan dan Hasil Tanaman Bawang Merah (Allium Ascalonicum L). Ganeç Swara, 4(2) : 81-86.

Maruapey A., dan Faesal. 2010. Pengaruh Pemberian Pupuk Kcl Terhadap Pertumbuhan dan Hasil Jagung Pulut (Zea Mays Ceratina. L). Serealita Nasional, 316-326.

Muharam. 2017. Efektivitas Penggunaan Pupuk Kandang dan Pupuk Organik Cair Dalam Meningkatkan Pertumbuhan dan Hasil Tanaman Kedelai (Glycine Max L.) Varietas Anjasmoro Di Tanah Salin. Agrotek Indonesia, 2(1) : 4453.

Neltriana N. 2016. Pengaruh Dosis Pupuk Kandang Kotoran Sapi Terhadap Pertumbuhan dan Hasil Ubi Jalar (Ipomea batatas L.). Skripsi Fakultas Pertanian Universitas Andalas.

Nurlisan., A. Rasyad. S. Yoseva. 2012. Pengaruh Pemberian Pupuk Organik Terhadap Pertumbuhan dan Hasil Tanaman Kedelai (Glycine Max (L.) 
Merril). Agronomi Indonesia, Volume 38 (1) : 25-29.

Paturohman E., dan Sumarno. 2015. Pemupukan Sebagai Penentu Produktivitas Ubi Jalar. Iptek Tanaman Panagan, 10(2) : 77-84.

Permanasari I., dan D. Kastono. 2012. Pertumbuhan Tumpangsari Jagung dan Kedelai pada Perbedaan Waktu Tanam dan Pemangkasan Jagung. Agroteknologi, 3(1) : 13-20.

Purwaningsih S. 2009. Populasi Bakteri Rhizhobium di Tanah pada beberapa Tanaman dari Pulau Buton, Kabupaten Muna, Propinsi Sulawesi Tenggara. J. Tanah Trop, 14(1) : 65-70.

Pusat Data dan Informasi Pertanian. 2016. Outlok Komoditas Sub Sektor Tanaman Pangan Ubi Jalar. Jakarta: Kementrian Pertanian.

Rahmi., Z. Fuady., dan Agusni. 2017. Pengaruh Waktu Aplikasi dan Pemberian Pupuk Organik Terhadap Pertumbuhan dan Hasil Kedelai (Glycine Max L.). Agrotropika Hayati, 4(4) : 245-258.

Rastono A., Sugiyarto., Marsusi. 2015. Pertumbuhan Carica (Carica Pubescens) yang Ditanam Secara Tumpangsari dengan Ubijalar (Ipomoea Batatas L.) dan Cabai Rawit (Capsicum Frustescens L) Di Lereng Gunung Lawu. ELVIVO, 3(2) : 1-8.

Rosmarkam A., dan Nasih W. Y. 2002. Ilmu Kesuburan Tanah. Kanisius: Yogyakarta.

Salisbury dan Ross. 1992. Fisiologi Tumbuhan. Institut Teknologi Bandung, Bandung.

Sari R, dan Retno Prayudyaningsih. 2015. Rhizobium: Pemanfaatannya Sebagai Bakteri Penambat Nitrogen. Info Teknis EBONI, 12(1) : 51-64.

Samuli L. O., L. Karimuna. dan L. Sabaruddin. 2012. Produksi Kedelai (Glycine Max L. Merrill) pada Berbagai Dosis Bokashi Kotoran Sapi. Agronomi, 1(2) : 145-147.

Setiawan H. P. 2016. Alih Fungsi (Konversi) Lahan Pertanian Ke Non Pertanian Kasus Di Kelurahan Simpang Pasir Kecamatan Palaran Kota Samarinda. Sosiatri-Sosiologi, 4(2) : 280-293.

Soenyoto E. 2014. Pengaruh Dosis Pupuk Phonska dan Penggunaan Mulsa Terhadap Pertumbuhan dan Produksi Tanaman Ubi Jalar Ungu (Ipomea Batatas L.) Varietas Ayamurasaki. Cendekia, 12(3) : 100-107.

Susanto E., Ninuk H., dan Nur E. S. 2014. Repon Pertumbuhan dan Hasil Tanaman Ubi Jalar (Ipomoea batatas L.) pada Beberapa Macam dan Waktu Aplikasi 
Agritrop, Vol. 16 (1): 38 - 60

Bahan Organik. Produksi Tanaman, 2(5) : 412-418.

Yelianti U., Kasli., M. Kasim., dan E. F. Husin. 2009. Kualitas Pupuk Organik Hasil Dekomposisi Beberapa Bahan Organik dengan Dekomposernya. Akta Agrosia, 12(1) : 1-7.

Zuchri. 2007. Optimalisasi Hasil Tanaman Kacang Tanah dan Jagung dalam Tumpangsari Melalui Pengaturan Baris Tanam dan Perompesan Daun Jagung. EMBRYO, 4(2) : 156-163. 